\title{
A weekends shopping behavior of women consumer with special reference to Retail outlets in Chennai
}

\author{
V. Anitha, A.R Krishnan
}

\begin{abstract}
The Indian retail industry has the financial records has around ten percentage on the country's GDP \& also nearly 8 percentage share with the employment. Our country is the world fifth leading international destiny into a retail space. Indian retail market is anticipated almost twice over to "US Doller 1 trillion by 2020". At the same time as the overall market is estimated to maximize at twelve percentage per year, in particular Modern Trade would enlarge double as speedy at twenty percentage per annum. This study is focused towards understanding consumer's shopping behavioral attitude \& perception also to quantify the consumer's persistent on preferred days.

The statistical techniques of factor analysis are used to analyze data collected from 150 women respondents in Chennai from specified modern outlets and applied convenience sampling with the help of SPSS. The finding contributes to the consumer's shopping behavior on weekdays and weekends hence consumers are examined behavioral attitude \& perception also evaluated the persistent of shoppers for these two different days. The result indicates that maximum percentages of people are preferred to encompass the shopping on weekends
\end{abstract}

Index Terms: Consumer behavior, Perception, Attitude, Shopping decision.

\section{INTRODUCTION}

Consistently there are a most extreme number of retailers from the world, they offer numerous items and administrations to their billions of shoppers. In a large portion of the nations, retailers and retail basically overwhelm the Indian economy's capacity. Huge retailers, for example, Walmart, carryfour are notwithstanding delivering more income similarly (for this situation, more than $\$ 400$ billion) than different nations. To achieve this circumstance, the retailers have needed to abuse the sources at their disposing of to offer methodologies that give one of a kind customer advantage in an ever-dynamic condition. Particularly the retail business' immersion level in India brings noteworthy open doors towards outside just as household players. A consistent adjusting way of life of the Indian purchasers makes the things significant for the retailers to be familiar with the example of utilization. The dynamic utilization example creates changes in obtaining style of the shopper and furthermore the components that drive individuals into stores. Thus the key aim of this paper is to discover the thought processes that drive ladies shopper to purchase in retail establishments or shopping centers on ends of the week.

Revised Manuscript Received on July 05, 2019

V. Anitha, School of Management, SRM Institute of Science and Technology, Kattankulattur, Chennai, Tamizhnadu, India.

Dr. A.R Krishnan, School of Management, SRM Institute of Science and Technology, Kattankulattur, Chennai, Tamizhnadu, India .
A large portion of the Indian buys were going on in open market or most extreme number of medium size staple shops and retail shops. A purchaser by and large holds up outside of the shop and approach the merchant for what they need and for the most part the purchaser couldn't settle on a decision or watch an item from within the shop. Induction into the shop's rack or the item's extra room region were typically constrained. The purchaser necessities might be too favor towards sustenance items or family unit items they are regularly searching for; the retailer goes to the holder or rack or to the back of the store, brings it out and offers it available to be purchased to the purchaser. Every now and again the retailer may supplant with the substitute item, asserting that it is comparable or alike to the item that the shopper is searching for. By and large the item naturally has no cost name in these medium size retail shops; for the most part bundled merchandise must put on view the "greatest retail value" (MRP) generally, without referencing the value detail on the item the customer are ignorant of the cost and furthermore, it is a criminal offense to sell an item past the MRP. The businessperson can value the staple and family unit items emotionally, and two customers may pay various costs for a similar item around the same time however never will that cost be over the MRP. Cost is rarely consulted between the dealer and purchaser. The buyer for the most part does not have sufficient energy to analyze the item name, and don't have a decision to fabricate an educated choice between competition items.

\section{LITERATURE OF REVIEW}

The Indian retail industry and the way consumers shop are constantly developing. A few years back, we have seen a number of new apps, mostly which relevant to the mobile usage, modern technology, and savvier uses of data to create modified the effective shopping experience. Those new innovative consumers were often changing their preferences, expectations and how they purchase across different mode of channels. Retailer must continuously have to move around their strategies and stay appropriate with the right messaging and a right channel mix.

A purchaser conduct of customer is viewed as an undividable piece of showcasing. "Kotler and Keller (2011)" express that purchaser purchasing conduct is the itemized investigation of the methods for purchasing and discarding products, administrations and thoughts or encounters of the people, gatherings and association so as to fulfill their needs and needs.

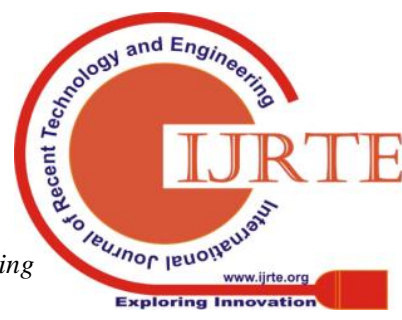


"Khan et al. (2014)" classify a scope of variables influencing shopper purchasing choice as (an) Outside Improvements (advancements and promoting, store shows, purchasing recurrence, climate); (b) Inner Observation like "feeling, way of life, cash, time weight and character", (c) A purchasing conduct like "value, installment and the season of acquiring"; and (d) A statistic Assortment like "age, sexual orientation, pay, occupation, conjugal status, and so on".. It was additionally expressed that the items which are identified with joy were purchased under drive purchasing and not the items which achieved pragmatic needs. The fundamental climatic elements like smell, style, appealing hues, inside structure, show of product, purpose of offer advancements caught purchasers' eye and set up their state of mind to purchase the scope of items. Purchaser qualities which incorporate temperament, sexual orientation, shopping pleasure and age likewise impacted client purchasing conduct. Notices were found to assume a significant job in structure the brand picture according to the clients. "Youn and Faber (2000) client buy conduct is affected by inward condition of the clients, for example, client prosperity, social intensity, accomplishment, social closeness, stress response, estrangement, hostility, control, hurt shirking, conventionalism and retention".

\section{RETAIL ATTRACTIVENESS IN INDIA}

India is a very shrewd goal for the retail division. As per GRDI, India was exceedingly positioned third. In a general Indian retail market is worth $\$ 410$ billion, out of which the offer of prearranged retail is minor $6 \%$, implying that arranged retail in India is having most extreme extension. The offer of arranged retail is foreseen to achieve $10 \%$ by 2013 in light of the mounting working class testing predominant subjective shopping surroundings and most grounded brands. The Indian retail market is gradually developing and retailers are centering themselves towards beneficial development. Amid the downturn, a large number of the residential retailer's tallying Subhiksha and Magnet has just outflanked 104 from the market, while a portion of the others like bharti retail have opened 59 stores in Northern India, Bharti Wal-Bazaar is unsurprising open 10-15 discount market areas in next three years. Correspondingly, Imprints and Spencer are wanting to come later on with one progressively extra outlet of the market retailers from the market. Perceived retailers are attempting to build up their business development by receiving the imaginative stores arrangement such like network shopping, town shopping centers and goal shopping stores.

\section{Attitudes \& Beliefs}

In multifaceted consumer behavior, the consumers are highly participating towards the buying while perceive a notorious differences among brand. In this kind of consumer attitude will frequently impact especially when the product is not often purchase, by self communicative, perilous or luxurious. A client makes her own buy, later than create convictions and frames of mind about the inert items. The majority of the brands that are best on buys are those that convey their across the board subtleties clearly and productively.

\section{Perception}

Discernment is a persistent procedure of huge how an individual chooses, sort out and translate their tangible impression so as to give significance to their environment. Nonetheless, there is a hole exist between what we seek after and target reality. We can all the more likely perceive the people by insightful their inborn inclinations by the way they see others and how they decide.

\section{Store Choice}

There are maximum numbers of stores accessible for consumers mainly select a store for their preferred goods. The selection of a specified outlet has a undeviating effect on the behavior of consumer. The store selection is based on the family size and composition, Income level and Employment status etc..,

\section{Store position:}

An effect product positioning of the retail stores are vital. A region of enormous impact in the fields of retail managing along with the tactical Retail Outlet's Positioning. The retail person premeditated objectives are to be developed incorporate advertising and whole marketing programs surrounding a extensive series in marketing rudiments also to generate the Market Positioning within the vibrant complete situation. In the direction of create a marketing position, the retailer are strive to expand a store's images which is systematically predetermined and intended to demand to the store platinum consumers. A greatest outlet's image is the manufactured goods of attribute so as to most significant in forecasting consumer benefaction.

\section{Store distance:}

The most brilliant store's area and it's duty of separation to the stores have been truly broke down. The most extreme number of studies have been call attention to that, greatest number of purchaser are exceedingly impact towards the go through costs of buys "Darker 198923; Craig, Ghosh, and McLaffarty 198424" and stores place. Thus it participate like imperative job in the choosing the predetermined stores. Various investigation has apportioned and point the store's territory "Arnold, Oum and Tigert, 198325; Freymann, 200226" In store's decisions. This examination have additionally clarify the separation may not generally be the significant factor. "Guadagni, P. M. what's more, J.D.C. (1997) 27 found that for a demanding portioning the customers, a standout amongst the most ideal stores on a normal, the most remote away". All in all expense brought about on separation may be basic, balanced by qualities built up, accordingly as like store learning, improved format and so on., anyway there is a reasonable haired degrees of agreement on separation, influence the store's decision and consequently the utilization of separation is estimated as a forecaster of store decisions.

\section{Promotions:}

Store's special has been widely examines the region of the writing, specifically "Gehrt and Yan, (2004) and Kenhove et al. 1999". The term coming up, picking conduct, think about by specific gathering by Lai and Rao (1997) and furthermore by the "Bucklin and Lattin 1992" demonstrate 
the blended outcome, for the impacts of sorted dimension in market exercises on customer store's decision choice. While "voile (2001), explore, the temporary impact of store-level advancement on supermarket decision, however yield were fundamentals yet it will be powerless". Then again, it has regularly been acknowledged that, retailer frequently use promotional including cost limits and offers are expanding store traffic and energize buy. A "Walters (1991)" found that the advancement of items in a single store definitely lessen the offers' of choices additionally supplement in an opponent store. Despite the fact that the sign are fluctuated in the stores level, special exercises is likewise estimated, for example, troubling store's decision.

\section{OBJECTIVES OF THE STUDY}

This paper is related to the study on weekends shopping behavior in retail outlets.

1. To analyze women's consumer behavior and attitude towards weekends shopping.

2. To know the various perception parameters to prevail on the weekend shopping decision.

3. To find out the maintaining persistency level by consumers on weekend shopping.

4. To determine the customary satisfaction, intensity in weekends.

\section{Methodology}

. The study is descriptive in nature. Both primary and secondary data were adopted. Primary data were collected using a questionnaire to measure the consumer shopping behavior in retail outlet. Secondary data were collected from published sources like magazines, books, journals, annual report, etc. The questionnaires were distributed to the entry level women consumers in retail outlet in Chennai. The researchers structured questionnaire in the form of closed ended questions.The collected data was processed and analyzed using SPSS 20, to meet out the objectives of the study. Percentage analysis was performed to present the results.

\section{DATA ANALYSIS AND INTERPRETATION}

Table 1: Demographic variables of weekend shopping behavior on women

\begin{tabular}{|c|c|c|c|}
\hline & $\begin{array}{c}\text { Demographic } \\
\text { variables }\end{array}$ & $\mathbf{N = 5 0}$ & \% \\
\hline \multirow{3}{*}{$\begin{array}{c}\text { Spring to } \\
\text { mind }\end{array}$} & Purchase & 30 & 60.0 \\
\cline { 2 - 4 } & Entertainment & 13 & 26.0 \\
\cline { 2 - 4 } & $\begin{array}{c}\text { To Know the } \\
\text { product } \\
\text { availability }\end{array}$ & 5 & 10.0 \\
\hline
\end{tabular}

\begin{tabular}{|c|c|c|c|}
\hline & $\begin{array}{l}\text { To know } \\
\text { discount } \\
\text { details }\end{array}$ & 2 & 4.0 \\
\hline \multirow{3}{*}{$\begin{array}{l}\text { Best time } \\
\text { to go for } \\
\text { shopping }\end{array}$} & Weekdays & 5 & 10.0 \\
\hline & Weekends & 32 & 64.0 \\
\hline & $\begin{array}{c}\text { Nothing } \\
\text { specifically }\end{array}$ & 13 & 26.0 \\
\hline \multirow{3}{*}{$\begin{array}{c}\text { If } \\
\text { weekends }\end{array}$} & $\begin{array}{l}\text { Shopping as } \\
\text { family }\end{array}$ & 22 & 44.0 \\
\hline & Sunday's offer & 24 & 48.0 \\
\hline & $\begin{array}{c}\text { Product } \\
\text { Variability }\end{array}$ & 4 & 8.0 \\
\hline \multirow{5}{*}{$\begin{array}{c}\text { Reasons to } \\
\text { do } \\
\text { shopping } \\
\text { in retail } \\
\text { outlet }\end{array}$} & $\begin{array}{l}\text { Near to } \\
\text { residence }\end{array}$ & 9 & 18.0 \\
\hline & $\begin{array}{l}\text { Regular } \\
\text { customer }\end{array}$ & 7 & 14.0 \\
\hline & $\begin{array}{l}\text { Quality } \\
\text { Products }\end{array}$ & 19 & 38.0 \\
\hline & Price offers & 9 & 18.0 \\
\hline & $\begin{array}{l}\text { Quality } \\
\text { Service }\end{array}$ & 6 & 12.0 \\
\hline \multirow{3}{*}{$\begin{array}{c}\text { Advertise } \\
\text { ment } \\
\text { impulse }\end{array}$} & Yes & 18 & 36.0 \\
\hline & No & 6 & 12.0 \\
\hline & At times & 26 & 52.0 \\
\hline \multirow{3}{*}{$\begin{array}{c}\text { Preference } \\
\text { on } \\
\text { ambiance }\end{array}$} & Yes & 33 & 66.0 \\
\hline & No & 6 & 12.0 \\
\hline & Not always & 11 & 22.0 \\
\hline \multirow{4}{*}{$\begin{array}{c}\text { Frequency } \\
\text { on same } \\
\text { outlet }\end{array}$} & $\begin{array}{c}\text { Less than } 1 \\
\text { year }\end{array}$ & 7 & 14.0 \\
\hline & $\begin{array}{c}\text { More than } 1 \\
\text { year }\end{array}$ & 18 & 36.0 \\
\hline & $\begin{array}{c}\text { More than } 3 \\
\text { years }\end{array}$ & 10 & 20.0 \\
\hline & $\begin{array}{c}\text { More than } 5 \\
\text { years }\end{array}$ & 15 & 30.0 \\
\hline \multirow{3}{*}{$\begin{array}{c}\text { Often } \\
\text { change the } \\
\text { outlet }\end{array}$} & Yes & 34 & 68.0 \\
\hline & No & 15 & 30.0 \\
\hline & At times & 1 & 2.0 \\
\hline \multirow{3}{*}{$\begin{array}{c}\text { Reason for } \\
\text { often } \\
\text { change the } \\
\text { outlet }\end{array}$} & $\begin{array}{c}\text { To know other } \\
\text { products }\end{array}$ & 9 & 18.0 \\
\hline & $\begin{array}{l}\text { To compare } \\
\text { the discounts }\end{array}$ & 14 & 28.0 \\
\hline & $\begin{array}{l}\text { To know the } \\
\text { alternatives }\end{array}$ & 27 & 54.0 \\
\hline \multirow{3}{*}{$\begin{array}{c}\text { Preference } \\
\text { to the } \\
\text { outlet's } \\
\text { location }\end{array}$} & Yes & 25 & 50.0 \\
\hline & No & 9 & 18.0 \\
\hline & Not always & 16 & 32.0 \\
\hline
\end{tabular}


Table 2: Correlation

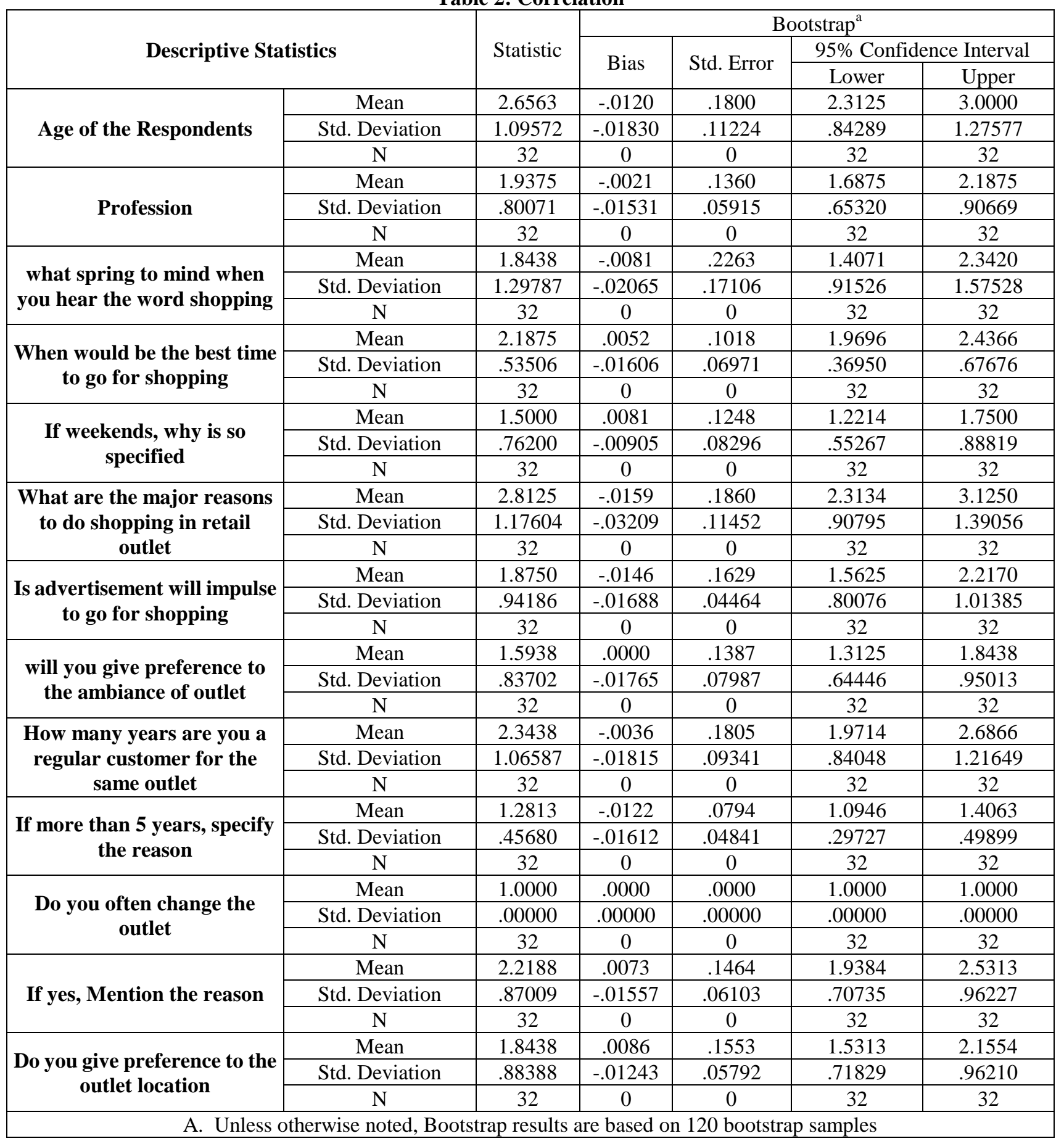

\section{1) Interpretation:}

- The majority of the respondents are thinking about the shopping mainly for the purchase $60 \%$ while Entertainment and to know the product availability were $26 \%$ and $10 \%$ respectively, $2 \%$ of respondents were to know the discount details.

- $64 \%$ of the respondents considered the best time for shopping is weekends while, nothing specifically and weekdays were $26 \%$ and $10 \%$ respectively.

- The maximum number of respondents mentioned weekends shopping specifically for Sunday's offer $48 \%$ while shopping as a family and product variability were $44 \%$ and $8 \%$ respectively.
- This data review shows that majority of the respondents specified the reason to do shopping in retail outlet for quality products $38 \%$ while near to residence and price offer \& regular customer were $18 \%, 18 \%$ and $14 \%$ respectively.

- level of the respondents expressed that advertisement will impulse to go for shopping at times only $52 \%$ while few respondents expressed yes and no were $36 \%$ and $12 \%$ respectively.

- The result indicates that majority of the respondents mentioned that giving preference to the ambiance of outlet will be yes $66 \%$ while not 
always and no were $22 \%$ and $12 \%$ respectively.

- Reviewed respondents on regular customer for the same outlet for more than 1 year as $36 \%$ while more than 5 years, more than 3 years \& less than 1 year were $30 \%, 20 \%$ and $14 \%$ respectively.

- Most of the respondents expressed the change outlet yes for $68 \%$ while no for $30 \%$ respectively.

- The result indicates that the majority of the respondents mentioned the reason to change the outlet for to know the alternatives $54 \%$ while to know the other products and to know the discounts were $28 \%$ and $18 \%$ respectively.

- The more number of the respondents expressed the preference to the outlet's location as yes for $50 \%$ while not always and no were $32 \%$ and $18 \%$ respectively.

\section{FINDINGS FROM THE STUDY}

Out of 50 respondents nearly more than two third of the consumers said, shopping will spring their mind mainly for Purchasing. More than $60 \%$ of the consumers were preferred to do shopping on weekends. Two third of the consumers choosing weekends for Sunday's offer. The respondents opting retail outlet for getting quality of the products. $52 \%$ of the shoppers are not always impulse on advertisement for choosing the products.

More than three fourth consumers will give importance to the ambiance of the outlet. $36 \%$ of the respondance consumer used to do shopping in same outlet for less than year only . $68 \%$ of the data were saying that consumers are keep on shift the shopping location, 54\% main reason would be on to know the alternate products. Two third of the shoppers will give importance to the outlet's location.

\section{CONCLUSION \& RECOMMENDATION}

A detailed study describe the conclusion depends on the review of Literature also the Data analysis (Primary and Secondary). The main aim of the study was to empirically predetermine when \& how will be the women consumers are deciding to go for shopping and what are the criteria to playing a vital role to choosing the options in retail outlet. Percentage analyzes were highly perform to obtain the significant result commencing the datasets that was detail obtained by means of survey. The research reveals the data that women consumers mostly prefer to do shopping on weekends and they are focusing on Sunday offers also they would like to have a shopping as family. Also the advertisement is not creating the high level impact on purchase and they are giving importance to their outlet location.

For the future recommendation: The women consumers are mostly not sustain with the regular outlet, they are visiting the outlet for not even more than two years. Hence we need to highly concentrate the actual reason for frequent changing behavior. In this study the limited respondents were answered that they would like to see the alternatives. But here there is a further scope for the future research that, in what are all the ways the consumers are seeking the alternatives also what are their expectation to be retain for at least five years.

\section{REFERENCES}

[1] Ahn, K.H. and Ghosh, A., Hierarchical models of store choice. International Journal of Retailing, 4(5), 39 (1989).

[2] Donovan, R., and Rossiter, J., Store atmosphere: an environmental psychology approach. Journal of retailing, 58, 34-57 (1982).

[3] H.J.H.M Williems, A shopping behavior an empirical study into the appreciation of atmospheric characteristics of inner-city shopping areas given the shopper's motivational orientation, Oct 2002.

[4] http://rai.net.in/

[5] https://www.atkearney.com/global-retail-development-index

[6] https://retail.economictimes.indiatimes.com/etanalytics/reports/rep orts/the-2017-global-retail-development-index/510

[7] https://www.prnewswire.com/news-releases/india-1-and-china-2-t op-the-2017-at-kearney-global-retail-development-index-rankings $-300467912 . h t m l$ 